\title{
Risk assessment of occupational exposure to heavy metal mixtures: a study protocol
}

Fatma Omrane ${ }^{1,2,3^{*}}$, Imed Gargouri ${ }^{1,4}$, Moncef Khadhraoui ${ }^{1}$, Boubaker Elleuch ${ }^{1}$ and Denis Zmirou-Navier ${ }^{2,3,5^{*}}$

\begin{abstract}
Background: Sfax is a very industrialized city located in the southern region of Tunisia where heavy metals (HMs) pollution is now an established matter of fact. The health of its residents mainly those engaged in industrial metalsbased activities is under threat. Indeed, such workers are being exposed to a variety of HMs mixtures, and this exposure has cumulative properties. Whereas current HMs exposure assessment is mainly carried out using direct air monitoring approaches, the present study aims to assess health risks associated with chronic occupational exposure to HMs in industry, using a modeling approach that will be validated later on.

Methods: To this end, two questionnaires were used. The first was an identification/descriptive questionnaire aimed at identifying, for each company: the specific activities, materials used, manufactured products and number of employees exposed. The second related to the job-task of the exposed persons, workplace characteristics (dimensions, ventilation, etc.), type of metals and emission configuration in space and time.

Indoor air HMs concentrations were predicted, based on the mathematical models generally used to estimate occupational exposure to volatile substances (such as solvents).

Later on, and in order to validate the adopted model, air monitoring will be carried out, as well as some biological monitoring aimed at assessing HMs excretion in the urine of workers volunteering to participate.

Lastly, an interaction-based hazard index $\mathrm{Hl}_{\mathrm{int}}$ and a decision support tool will be used to predict the cumulative risk assessment for HMs mixtures.

Discussion: One hundred sixty-one persons working in the 5 participating companies have been identified. Of these, 110 are directly engaged with HMs in the course of the manufacturing process. This model-based prediction of occupational exposure represents an alternative tool that is both time-saving and cost-effective in comparison with direct air monitoring approaches. Following validation of the different models according to job processes, via comparison with direct measurements and exploration of correlations with biological monitoring, these estimates will allow a cumulative risk characterization.
\end{abstract}

Keywords: Occupational exposure, Heavy metals, Indoor pollution, Modeling, Mixture, Air monitoring, Biomonitoring

\section{Background}

Several heavy metals (HMs) are considered to be among the most threatening toxic elements for human health, especially for residents neighboring industrial units and polluted sites [1]. The US Agency for Toxic Substances and Disease Registry (ATSDR) has established a Substance

\footnotetext{
* Correspondence: fatma.omrane@ehesp.fr; denis.zmirou@inserm.fr 'Laboratory of Environmental Engineering and EcoTechnology, National Engineering School of Sfax (LR16ES19) (ENIS), Sfax University, Sfax, Tunisia ${ }^{2}$ Lorraine University, Medical School, INGRES (EA 7298), Vandœuvre-les-Nancy, Nancy, France

Full list of author information is available at the end of the article
}

Priority List on the basis of substance frequency, toxicity, and potential for human exposure. Arsenic (As) is at the top of the list, followed by lead $(\mathrm{Pb})$ - and cadmium $(\mathrm{Cd})$ is in seventh place [2].

It is well documented in the literature that acute exposure to heavy metals can cause such harmful effects as lung inflammation $[3,4]$, hepatic cell destruction, kidney and neurological damage. It can also, unfortunately, be fatal [5]. Concern over chronic exposure to HMs is growing: in addition to its impact on health, it is cumulative in character and mixture-related effects have also been identified [6]. In this context, it is worth noting 
that even in trace amounts, HMs are pollutants of concern because of their toxicity, implication in cancers and neurologic impairments [3, 4, 7], and bioaccumulation in living organisms [8-10]. Assessment of exposure to such metals therefore demands serious attention.

Within this frame, scientists usually use either a direct air approach coupled with biological monitoring, or a modeling approach - and in some cases, a combination of both. According to Jayjock et al. [11], modeling should be considered a more important element in exposure assessment, because of the growth of the number of chemicals that need to be assessed and the health impact they may induce, due to their existence in mixtures [11].

Of the different models available, we are using mathematical models to predict indoor air concentrations of pollutants based on environmental working conditions as well as certain other specific information about the manufacturing process [12]. These models were initially developed for solvents and other volatile compounds, in relation to their physicochemical proprieties. With regard to metals, to the best of our knowledge, similar models were applied only to arc welding process, in a study in which Boelter et al. [13] calculated field-derived emission rates of total particulate, encompassing only iron and manganese.

In this study, we aim to broaden the application of these mathematical models to HMs, as well as to several types of emission in various production processes.

It is worth noting that most current chemical risk assessment studies on HMs address isolated and single substances [14-16]. Industrial processes can however result in exposure to a variety of HMs simultaneously and/ or consecutively [17]. Consequently, this can be regarded as a gap in the prediction of the biological organism's response when exposed to a mixture of toxic chemicals. This is considered one of the most challenging tasks in environmental toxicology and risk assessment [14]. We decided to assess the combined effects of mixtures so as to more realistically reflect occupational exposure, encompassing health effects possibly associated with their interaction [17].

\section{Methods}

Several studies conducted in the Sfax region have shown that industrial activities are generating multiple metallic pollutants affecting all three compartments of the environment (air, water and soil) [18-21] and where pollutants are found in soils $[19,20]$, surface and sub-surface sediments $[18,21,22]$ as well as in sea water along the Sfax coastline [23]. Several living beings have been proven to be affected, including marine organisms (fish, mollusks, cuttlefish, tuna, etc.) living near the industrialized coastline $[8-10,24-28]$ and the fishing harbor of Sfax $[18,29-32]$. Other studies dealt with populations from Sfax metropolis, where they have investigated the relationship between metallic pollution and certain illnesses [16, 33, 34]. These concerned coastal zone residents and the downtown population [35] and mention that professional exposure to HMs may be a probable factor in explaining the high risk of various cancers identified in the region. The metals most often accused are $\mathrm{Cd}$, followed by $\mathrm{Zn}, \mathrm{Pb}, \mathrm{Ni}, \mathrm{Cr}, \mathrm{As}, \mathrm{Cu}$, and $\mathrm{Hg}$ [8$10,16,18-21,23-39]$. For both the scientific communities and decision makers, then, the assessment of occupational exposure to such metals demands serious investigation. To achieve this, a study approach will be introduced and discussed.

\section{Study site}

Sfax is Tunisian's second largest city, and is considered the economic capital due to the presence of many industrial zones and its significant role in exports. Figure 1 shows the location map of industrial areas and the main sources of pollution in Sfax metropolis [40]. A figure file shows this [see Fig. 1]. In this region, residents living close to industrial zones are constantly exposed to metallic pollutants [1]; it is well documented that industrial releases $[1,8,18,24,31,35]$ are exceeding the heavy metal levels fixed by national standards [35].

\section{Study population}

The study involves workers directly exposed to HMs at their workplaces, and manipulating some of the abovementioned chemicals in manufacturing processes. For purposes of comparison, we also included administrative staff as indirectly-exposed employees.

In order to localize companies handling HMs, and to define the main pollutants of interest, we conducted a thorough review of earlier studies addressing metallic pollution in the Sfax metropolis $[8-10,16$, 18-21, 23-39]. In addition, with the help of the chamber of commerce, and following investigation of the local industrial sectors, we identified industries and companies we believe to be sources of $\mathrm{HMs}$ emissions [41]. A wide range of industrial activities was covered, including the steel and metal machining, electrical and wiring, electroplating, phosphate fertilizers, plastic, paint and glass industries. Lastly, we randomly selected one company from each industrial sector, and contacted company executives to request their cooperation. Where we were declined, we selected another company in the same sector and sought cooperation.

\section{Inclusion criteria}

The selected companies were industries manipulating HMs in their production processes likely to incur occupational exposure to a mixture of such chemicals. Metal 


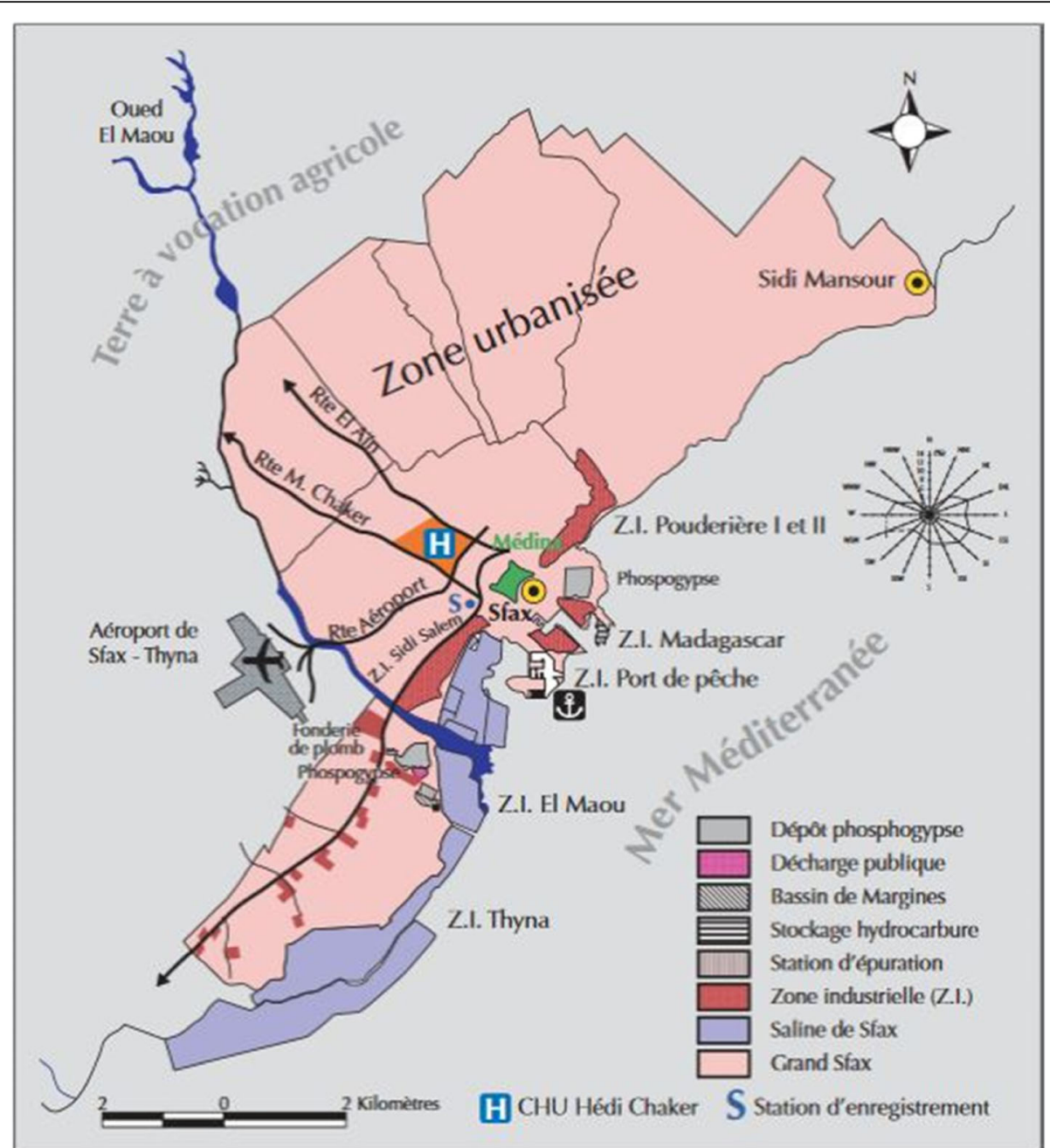

Fig. 1 Location map showing industrial areas and the main sources of pollution in Sfax metropolis [40]. Permission from the corresponding author: Imed Gargouri

manipulation had to be identified where small particles emission was found in the air as small particles aerosol (cold: dust; or hot: vapor).

\section{Exclusion criteria}

(i) Companies not manipulating HMs; (ii) and employees exposed to a single metal.

To solicit approval, we explained to the entrepreneurs, by written letter, the aim of the study and the probable risks to workers in industries manipulating HMs. We then used the first and the second questionnaires to collect the following information:

- Identification and definition of all substances manipulated in the processes, to ensure that our qualitative and quantitative inventory was as accurate as possible
- Definition of exposed and non-exposed employees, based on their activities and possible exposure to $\mathrm{HMs}$

- Description of the overall atmosphere of the workplaces and the nature and quality of ventilation in each workplace

- Identification of workers' position in relation to the emission source, for each job in every workplace

The questionnaires were used to collect information for the modeling scenarios in view to choose the proper model types or to calculate their parameters.

\section{Study design}

It is worth noting that the Qualitative Human Health Risk Assessment (QHHRA) was introduced in 1983 by the National Research Council (NRC) in the United States [42-44]. This scientific approach allows 
knowledge to be organized through use of a standardized, transparent and coherent methodology [43]. It has four steps [44]: (i) hazard identification, (ii) dose response assessment, (iii) exposure assessment, and (iv) risk characterization.

In our workplace exposure assessment study, we will use three approaches: (i) estimation of pollutant concentrations using mathematical models for occupational exposure [45]; (ii) performance of direct measurements of indoor air HMs concentrations, comparing them with the theoretical results and then validate the used models [46] and (iii) biological monitoring of HMs in the urine of workers volunteering to participate, to check correlation with model estimations [47].

\section{Exposure assessment}

\section{Occupational exposure modeling}

Recent developments in modeling allow prediction of exposure to chemicals, using descriptive environmental and/or the human physiological factors. According to the selection criteria for the chosen companies, inhalation is the main exposure route. We have therefore applied mathematical models to estimate occupational exposure to airborne pollutants [45]. In this frame, a variety of models is used to predict indoor air pollutant concentration. The models differ in their hypotheses as to (i) pollutant transport mechanisms and (ii) uniformity of the air mixture in the workplace.

These models were executed using IHMOD "Industrial Hygiene Modeling" software, $[48,49]$ which is a model compilation for the calculation of inhalation concentration. It is available from the American Industrial Hygiene Association (AIHA) website [48]. IHMOD currently offers 12 models. The three most commonlyused categories are: (i) the Well Mixed Box, (ii) the Near Field and Far Field model and (iii) the Eddy Diffusion Turbulent model [12]:

(i) The Well Mixed Box suggests a simplified representation of chemicals dispersion. It estimates the air concentration of a completely well mixed room. The input parameters are the emission or generation rate " $G$ ", ventilation rate " $Q$ " and the volume of the air in the workplace "V".

(ii) The Near Field and Far Field model (NF-FF: 2 zone model) tries to provide a more accurate pollutant estimation for employees working near the emission source. It divides the workplace into two zones, conceptually. The Near Field (NF) includes the emission source and the worker's breathing zone. The Far field (FF) is the remaining volume of the workplace, where pollutant concentrations are probably lower, and assumed to be homogeneous.
(iii)The Eddy Turbulent Diffusion model considers pollutant diffusion to be greater than molecular diffusion. It estimates pollutant concentrations using the radial distance of workers and the physical limits of the workplace as inputs, and requires locating the worker in relation to the emission source.

\section{Models choice}

The main criteria for selection of the appropriate model are (i) the worker's position and localization in relation to the emission source and (ii) the configuration of workplace ventilation [12]. Indeed, variability or steadiness of the job process in time and space is an important factor in choosing a model subtype, which is why a study of each job process is necessary to model selection. Moreover, in order to calculate model parameters, it is necessary to conduct a questionnaire about job and workplace specifications, as well as perform certain direct measurements. These are specified in the next section.

\section{Model parameters}

Some key parameters are present in all models: (i) ventilation rate "Q", (ii) air volume "V", and (iii) generation rate "G"

\section{a. Ventilation rate " $Q$ ":}

First of all, we need to verify mass conservation of the quantity of matter in the air, so as to prove that there is no backpressure effect in the workplace. Confirmation of the basic assumption allowing calculation of the ventilation rate for the whole workplace is a necessary prestep. This assumption considers air in the workplace room to be an ideal gas, and that the air flow rate entering the room is equal to the air flow rate leaving it.

Mass conservation is calculated following the basic formulas of the ideal gas law:

$$
P_{\text {in/out }} \times V=n_{\text {in/out }} \times R \times T_{\text {in/out }}
$$

Where:

Pin/out: the air pressure entering or leaving the workplace room in Pascal $(\mathrm{Pa})$.

$\mathrm{V}$ : the air volume $\left(\mathrm{m}^{3}\right)$;

$\mathrm{n}$ : the quantity of matter (mol);

R: the ideal gas constant (unit J. $\mathrm{K}^{-1} \cdot \mathrm{mol}^{-1}$ );

$\mathrm{T}$ : the temperature inside or outside the workplace in Kelvin (K).

So, it is necessary to demonstrate that the quantity of matter entering and leaving the room is approximately the same.

$$
n_{\text {in }} \approx n_{\text {out }}
$$

We therefore calculate that $\mathrm{n}_{\text {in }} / \mathrm{n}_{\text {out }}$ should be approximately equal to 1 . 
To this end, direct measurements of pressure and temperature inside and outside each workplace should be performed prior to using the method described below to calculate Q [12].

In our case, open doors and windows are the only or major source of ventilation; air comes in and out of these two openings, generally located at opposite ends of the rooms. We assume air direction to be constant, therefore:

$$
Q_{\text {in }}=Q_{\text {out }}
$$

To calculate $\mathrm{Q}_{\text {in }}$ entering from the main door, we measured average air face velocity " $\mathrm{V}_{\text {face }}$ " through the door over the time range of interest ( $4 \mathrm{~h}$ shift), and recorded the dimensions of the doors.

The average " $Q$ " within the volume of interest is calculated using the following formula [12]:

$$
Q_{\text {average }}=V_{\text {face }_{\text {average }}} \times S
$$

Where:

$\mathrm{V}_{\text {face average: }}$ average air face velocity $\left(\mathrm{m} \cdot \mathrm{s}^{-1}\right)$.

$\mathrm{S}$ : the surface of the main door or source $\left(\mathrm{m}^{2}\right)$.

Throughout this study, air face velocity measurements will be conducted for $8 \mathrm{~h}$ across two different periods, to assess variations during, and between, days. This will also be performed across different seasons, to get an idea of the variability of $\mathrm{Q}$ in the workplace.

\section{b. The air volume " $V$ ":}

Workplace dimensions are used to calculate the volume of the rooms. Specific volumes within the room are also considered, such as an upstairs floor inside the room, or stocks of raw materials or manufactured products. Machine volumes are also accounted for, either by gathering information from managers, or measured by the authors.

\section{c. The generation rate " $G$ ":}

Two main methods are used: (i) mass balance and (ii) Emission Factor (EF).

\section{The mass balance method}

During the manufacturing process, product masses are maintained. The quantity of pollutant emitted into the workplace can thus be calculated using the eq. [12]:

$$
\begin{gathered}
\text { mass }_{\text {into process }}-\text { mass }_{\text {incorporated into product }}-\text { mass }_{\text {collected as waste }} \\
=\text { mass }_{\text {released in room }}
\end{gathered}
$$

We have to take into account the division of the mass per time (production per year for example). The result is an average $\mathrm{G}$.
To use the mass balance method, all forms of metal transformation during the processes are evaluated: metal end-products, mass collected as waste (often sold to other companies for other usages), and particulate matter deposited on the workplace floor. The difference between the sum of the latter and the raw metal quantity will be the suspended aerosol. Concentrations of the various HMs within this aerosol will be assessed.

To achieve accurate prediction, it is necessary to consider the fraction of particles deposited on the floor so that the mass balance method does not overestimate indoor air concentration of HMs. To this end, we will collect the metal dust deposited on the floor of the workplace. This collection will be made at the end of the week and the end of the shift. We will then subtract the corresponding amount of each metal from the quantity released into the air. The proposed equation is the following:

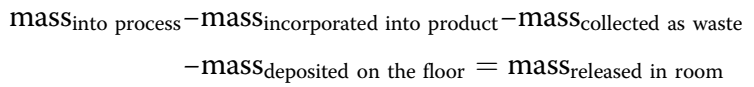

\section{The Emission Factor (EF) method}

An EF is calculated for a specific process, and sometimes for specific parameters and conditions. It relates the quantity of pollutants to a particular activity. It facilitates estimation of the generation rate, especially where there is a lack of information or difficulty in calculating it [12]. USEPA (US-Environmental Protection Agency) has used EFs extensively to assess air pollution related to industrial emissions, compiling this data in the AP-42 Compilation of Air Pollution Emission Factors [50]. The common equation for emissions estimation is the following [50]:

$$
\text { Emission }=A \times E F \times\left(\frac{1-E R}{100}\right)
$$

\section{Where:}

$\mathrm{A}=$ activity rate;

$\mathrm{ER}=$ overall emission reduction efficiency, in \%

Generally, the EFs in AP-42 are calculated from all acceptable quality studies. Identification of true emission factors at a specific plant is difficult. For this reason, we recommend AP-42, which provides tools for the estimation of emission factors applicable to the situation of interest [50]. In this investigation, since we were unable to find EFs for each process, we attempted to retrieve the information from external studies. In order to cope with these uncertainties, a Monte Carlo simulation will be undertaken [12].

\section{Air monitoring methodology}

Later on, indoor air HMs concentrations will be measured using (i) personal samplers set up near the worker's breathing zone, or (ii) fixed samplers placed in 
the workplace at average height corresponding to the breathing zone.

The samplers include 3 sections of clear styrene filter cassette, with a diameter of $37 \mathrm{~mm}$ (Cassette $\mathrm{SKC}^{\circ}$ SKC2253050LF) [51, 52], containing Quartz Filters with porosity of $1.2 \mu \mathrm{m} \mathrm{SCS225} 1827$ [53]. The air flow rate of the personal sampling pump Pump SKC ${ }^{\bullet}$ will be regulated to $2 \mathrm{~L} / \mathrm{min}[13,54,55]$, using the method and analytical procedures provided by INRS (French National Research and Safety Institute for the Prevention of Occupational Accidents and Diseases) [52]. Air monitoring will cover a four-hour shift [56-58].

\section{Biological monitoring methodology}

To quantify the amount of HMs penetrating into the body, urine samples will be collected from both exposed and non-exposed employees volunteering to participate.

HM concentrations will be quantified in urines in elementary form. Sampling and analytical methods will follow the US-NIOSH, 'National Institute for Occupational Safety and Health', 8310 method [47].

\section{Models validation method}

These mathematical models have been particularly applied to solvents and other volatile compounds in the literature. Several studies demonstrated that their predicted concentrations are "reasonably" comparable to air monitoring measurements within a factor of 0.5 to 2 folds [12].

As previously mentioned, regarding metals, to the best of our knowledge, similar models were applied only to arc welding process [13]. In contrast to our approach, Boelter et al. [13] calculated some models' parameters based on air monitoring measurements. Therefore, in our study, a validation step is necessary to evaluate the models estimations by comparing the model estimates to air concentrations measurements.

For statistical considerations and in order to minimize the natural variability of concentration measures, we will conduct six replicate measurements, as recommended by the AIHA Exposure Assessment Committee [12]. Nevertheless, the measured values depend on many factors such as the ventilation rate (which may vary across days according to meteorology), the workers activity profile (e.g. number of tasks per day, which may also vary between workers and from day to day), etc. For the statistical analyses, if the distribution of the six replicates show normal, the mean value will be adopted, otherwise, the median will be used. Additionally, to avoid the underestimation or overestimation of some situations where the exposure is significantly higher or lower than the median values due to natural variability, we decided to also validate a second scenario where we will compare the mean predicted values with the mean measured values.

To evaluate the match between measured and predicted HM exposure levels, we adopted two statistical techniques, based on the literature [13, 59-62], respectively regression analysis and testing the difference between the paired values (mean of the modeled HMs concentrations and the mean/median of measured ones), with dependent $\mathrm{T}$-tests or nonparametric Wilcoxon signed-rank tests, as appropriate. All statistical analyses will be achieved using IBM SPSS Statistics, version 20 .

\section{Risk characterization}

Risk characterization aims to describe and quantify the effect of exposure to HM mixtures. Initially, in order to explore internal doses in target organs/tissues, we intended to use a PBPK (Physiologically Based Pharmacokinetic) model [63]. Thought PBPK models have been used extensively for mixtures such as organic solvents, this is not, to the best of our knowledge, the case for HM mixtures [64], probably due to the extreme variability of the biological half-lives of the main toxic HMs which range from days for As to decades for $\mathrm{Pb}$ [65].

Bearing this in mind, other approaches and tools will be used to characterize the risk of exposure to $\mathrm{HM}$ mixtures. The interaction based Hazard Index $\mathrm{HI}_{\text {int }}[66,67]$ is a modified Hazard Index that takes into account binary interactions data between chemicals. It was initially introduced by the US-EPA [68] to improve the doseadditive hazard index, which underestimates cumulative risk. Toxicological interactions are poorly quantified and generally studied using simple models that include two chemicals. For this reason $\mathrm{HI}_{\text {int }}$ includes qualitative methods aimed at appraising the "weight of evidence" of the available information on interactions [68].

The most recent revised formula is as follows [67]:

$$
H I_{I N T}=\sum_{j=1}^{n} H Q_{j} \cdot\left(\sum_{k \neq j}^{n} f_{j k} \cdot\left(M_{j k}\right)^{B_{j k} \cdot g_{j k}}\right)
$$

$M_{j k}$ is the magnitude of the interaction; $B_{j k}$ is the weight of evidence score for the interaction of chemical $j$ affecting toxicity of chemical $\mathrm{k}$, these are fixed by US EPA; $f$ and $g$ are two exposure-dependent functions.

We will use a decision support tool named "Mixie" to look for interactions described in the literature. Mixie was developed by Montreal University and the "Institut de recherche Robert-Sauvé en santé et sécurité au travail" [69], and revised by the INRS in the French version [70]. This software assesses multi-exposure to chemicals in occupational settings. Its database contains 218 analysis sheets for chemical couples, and illustrates their combined effects. 
In addition, in case of lack of information on Toxicity Reference Values (TRV), "Mixie" can be used to calculate the "Exposure index" $\mathrm{Rm}$. This is an index using only Time-Weighted-Averages of Threshold Limit Values (TLV) - or VLEP (Valeurs Limites D'Exposition Professionnelle) in the French version.

\section{Preliminary results and discussion Descriptive results}

We stress that participation in this study is voluntary, both at the level of industrial plants and workers. To conduct the study, we began by identifying 53 companies from the selected metals sectors, then we chose 17 from each activity. In the end, only 5 industrial plants agreed to be involved. The corresponding industrial sectors are the steel cutting, welding, electroplating and plastic industries.

This study thus relates to 161 workers. According to the questionnaire results, 110 of these workers directly handle metals; most of these (83.2\%) are men.

Next, we identified the raw materials and products with relation to each industrial plant by means of the identification/descriptive questionnaire, and sought out their chemical compositions in order to identify which HMs might be released during the manufacturing process. The main metals found are $\mathrm{Cu}, \mathrm{Zn}, \mathrm{Ni}, \mathrm{Pb}$ and $\mathrm{Cr}$; we also added aluminum $(\mathrm{Al})$ because it was found in most of the studied companies.

The existing metals at each company, and the combinations of mixtures to be assessed are shown in Table 1.

The second survey conducted allowed us to find out about the process of each job, with a view to assessing the risk specific to each process. Direct measurements of pressure and temperature were taken, to check their invariance by calculating the mass conservation of the in and out flow air in each workplace room. Every quantity of matter ratio was close to 1, showing good mass conservation.

\section{Modeling example}

We illustrate the modeling approach using an example that relates to electric arc welding at the company referred to as " 2 " in Table 1, where one worker is exposed,

Table 1 Metal used in the industrial processes at the companies

\begin{tabular}{lllllll}
\hline Companies & $\mathrm{Al}$ & $\mathrm{Cu}$ & $\mathrm{Cr}$ & $\mathrm{Ni}$ & $\mathrm{Pb}$ & $\mathrm{Zn}$ \\
\hline 1 & + & + & + & + & - & - \\
2 & + & + & + & + & + & - \\
3 & + & + & - & - & - & + \\
4 & - & + & + & + & - & + \\
5 & + & + & - & - & - & + \\
\hline
\end{tabular}

$(+)$ : Presence of the metal, $(-)$ : Absence of the metal close to the emission source. The metals emitted are $\mathrm{Cr}$ and $\mathrm{Ni}$.

There is neither a control system nor mechanical ventilation in the workroom. Because of a low airflow rate nearby the welder, the welding fumes are concentrated in the surrounding area. Therefore, we use the NF/FF model with a constant emission rate. The workplace is divided, conceptually, into two zones, respectively near and far fields.

The NF is estimated as half-hemisphere. The radius $(1.15 \mathrm{~m})$ lies between the welder and the metallic piece being welded (the emission source). Vertically, the radius actually covers the distance between the welding level up to $15 \mathrm{~cm}$ above the worker's head to include the entire breathing zone. The NF volume is equal to $1.59 \mathrm{~m}^{3}$. Air velocity measurements and main door dimensions were used to calculate the room ventilation rate $Q$, which is equal to $137.85 \mathrm{~m}^{3} \cdot \mathrm{min}^{-1}$. Air volume calculations were made using the workshop and stocks dimensions, and were found to be equal to $593.57 \mathrm{~m}^{3}$. Another specific parameter of the NF-FF model is $\beta$, the interbox air flow rate, which is equal to $7.42 \mathrm{~m}^{3} \cdot \mathrm{min}^{-1}$. This is calculated using the free surface area of the near field and average air velocity near the NF. The free surface area is the air surface of the NF volume. US-EPA dealt with the Electric arc welding process in AP 42 [71] and provides EFs for $\mathrm{Cr}$ and $\mathrm{Ni}$ depending on electrode type. They quantified the emission factors for the electrodes used in Company "2". The electrode references are E7018 [72] and E6013 [73].

These emission factors are rated as average factors, developed from robust and/or new methodologies applied to a reasonable number of facilities [50]. Based on these EFs, we calculated the generation rates $G$ for each metal (Table 2). Then we used the IHMOD [48, 49] software for the NF-FF model, with a constant emission rate.

\section{Discussion}

Usage of mathematical models for estimating occupational exposure to HMs is considered an economic and time-saving tool, in comparison with direct air monitoring. The latter demands sophisticated and expensive

Table 2 Emission factors, generation rates and modeled concentrations of $\mathrm{Cr}$ and $\mathrm{Ni}$ resulting from electric arc welding at Plant 2

\begin{tabular}{lll}
\hline Metal & $\mathrm{Cr}$ & $\mathrm{Ni}$ \\
\hline EF $(\mathrm{g} / \mathrm{kg})$ of E7018 consumed & 0.006 & 0.002 \\
EF $(\mathrm{g} / \mathrm{kg})$ of E6013 consumed & 0.004 & 0.002 \\
Generation rate G $(\mathrm{mg} / \mathrm{min})$ & 0.0180 & 0.0064 \\
Modeled Concentration NF ss $\left(\mathrm{mg} / \mathrm{m}^{3}\right)$ & $25.210^{-4}$ & $8.910^{-4}$ \\
Modeled Concentration FF ss $\left(\mathrm{mg} / \mathrm{m}^{3}\right)$ & $1.2710^{-4}$ & $0.45210^{-4}$
\end{tabular}

EF emission factor, NF near field, FF far field, ss steady state 
equipment, as well as long and rigorous chemical analysis in the laboratory. Even though air measurement is needed to validate the models, IHMOD models are easily repeatable and can be used to assess and control HM emissions whenever a company changes any of the conditions affecting the parameters of the models. These models have now been used to predict volatile compound concentrations [12]. They had yet to be validated for certain processes involving metals manipulation. Later on, in an attempt to do so, we will use at least six different measurements to validate a single model estimation.

The original mass balance eq. [12] does not consider the quantity of deposited metallic dust, which could yield overestimation of exposure, especially when considerable quantities of deposited dust are observed (especially in steel cutting job tasks).

Aerosol deposition was considered by Schneider et al. [74] in a NF-FF model. He described dust deposition as an equivalent air exchange rate that leads to mass loss of particulate matter from air to the floor or other surfaces. This notion was also discussed by Reinke and Keil in Mathematical Models for Estimating Occupational Exposure to Chemicals [12] and was named a "sink" or non-ventilatory loss of mass. They considered it as a proportional factor to the estimated pollutant concentration. However, they highlighted that it is usually disregarded in modeling because it is extremely difficult to estimate.

In order to remedy overestimation and to quantify the mass loss of dust, we consider this mass loss as a fixed amount when computing the generation rate G. Thus, we will collect the dust in the two companies where the mass balance method is adopted, at the end of the week shift and weigh it for integration in the mass balance equation. As an approximation, we neglected the contribution of outdoor airborne particle sources (due to the small air exchanges in the workplaces) and we assumed that the collected dust contains only metallic dust.

This exploratory step will allow assessment of the order of magnitude of the impact of considering deposited dust when estimating workplace air concentrations of metals.

The EF method used to calculate the generation rate has some limitations. We were unable to calculate EF for every job process, because AP-42 considers a limited number of industrial sectors. The compatibility of the EFs constructed in the US setting is questionable. We think this might not be too problematic, because EFs were developed for specific job processes, and often provide conditions with which to calculate one's own EFs. The US-EPA illustrated EFs from all acceptable-quality studies conducted across a wide range of facilities and circumstances, and states that the calculated emission factors are representative of long-term averages for all facilities having the same kind of source [50].

We undertook calculation of the air mass conservation and were able to confirm that the quantity of matter entering and leaving the workshops is almost the same, the most likely reason being that the major ventilation sources are doors and windows. Concentrations of both $\mathrm{Cr}$ and Ni were estimated using the NF- FF approach at one plant. $\mathrm{C}_{\mathrm{FF}}$ were found to be 19 folds lower than $C_{N F}$, due to the high $Q$ value - the room being highly ventilated, with two large doors facing one another. $\mathrm{C}_{\mathrm{NF}}$ for both $\mathrm{Cr}$ and $\mathrm{Ni}$ were below the Occupational Exposure Limit values (OELs) from the Mixie tool (Canada) [69], 0.5 and $1 \mathrm{mg} / \mathrm{m}^{3}$, respectively. We used the safest international OELs, since there is no Tunisian equivalent. Comparing these with the Toxicity Reference Values (TRVs) issued by various international bodies, these levels cannot be considered safe. Health Canada, for example, mentions pathological changes in the morphology and function of alveolar cells having a Tolerable Concentration (TC) for metallic $\mathrm{Ni}$, equal to $0.018 \mu \mathrm{g} / \mathrm{m}^{3}[75,76]$ - a value about 50 times lower than the air concentrations estimated in our example. This could have serious implications for the worker's health, before even considering the presence of other metals.

\section{Conclusion}

The main aim of this study was to assess health risks associated with occupational exposure to HM mixtures at several industrial plants in Sfax, Tunisia. In this first part of this investigation, we presented the methodology for doing this and applied mathematical modeling that predicts metal concentrations in the electric arc welding process workplace that are below regulatory values. These preliminary results will be cross-referenced against air concentration measurements and biological monitoring of urine from workers volunteering to participate.

This study will be continued for all other metals listed in Table 1, as well as for the other industrial sectors.

The final step of this study will consist of a risk characterization stemming from cumulative exposure to several toxic metals.

\footnotetext{
Abbreviations

AlHA: American Industrial Hygiene Association; ATSDR: Agency for toxic substances and disease registry; $\mathrm{Hl}_{\text {int }}$ : Interaction-based hazard index; HM: Heavy metal; IHMOD: Industrial hygiene modeling software; NF-FF: The near field and far field model; NRC: National Research Council; OEL: Occupational exposure limit value; PBPK: Physiologically based PharmacoKinetic model; QHHRA: Qualitative human health risk assessment; Rm: Exposure index; TC: Tolerable concentration; TLV: Threshold limit values; TRV: Toxicity reference value; US-EPA: Environmental Protection Agency in the United States; US-NIOSH: National Institute for Occupational Safety and Health in the United States; VLEP: Valeurs Limites d'Exposition Professionnelle
} 


\section{Acknowledgements}

Not applicable.

\section{Funding}

The study was funded by Sfax University, Tunisia in collaboration with EHESP (Ecole des Hautes Etudes en Santé Publique, France).

\section{Availability of data and materials}

The datasets generated and/or analyzed during the current study are not publicly available due to data confidentiality, but are available from the corresponding author on reasonable request.

\section{Authors' contributions}

FO contributed to study conception and design, acquisition of data, analysis and interpretation of data, and also wrote the first draft of the manuscript and revised it with contributions from all authors. IG contributed to study conception and design, as well as to contacting the companies, and has been involved in critical revision of the manuscript. MK was involved in revising and structuring the manuscript. $B E$ contributed to contacting the companies, and attended initial meetings with their managers. DZN was involved in revising the study conception and manuscript critically, and has given final approval for the version to be published. All authors have read and approved the final manuscript.

\section{Ethics approval and consent to participate}

In our situation, we needed company approvals corresponding to the equivalent of study approval. Our study deals with indoor air pollution in companies using heavy metals and its negative health impacts, without any direct contact with the workers. The only procedure we needed "consent to participate" in was the urine sampling. Samples are taken from workers who decide freely whether they want to participate. We seek their approval as to when the sampling will be carried out.

We received written informed consent from the study participants. The managers of all the companies approved and signed up to participate in our study. We also received a formal letter from the National Southern Independent Ethics Committee (Comité de Protection des Personnes Sud) under the reference number: CPP Sud 0034/2017. The letter states that our study complies with the ethical rules in our country. The committee reviewed the study and gave us a favorable opinion.

\section{Consent for publication}

Not applicable

\section{Competing interests}

The authors declare that they have no competing interests.

\section{Publisher's Note}

Springer Nature remains neutral with regard to jurisdictional claims in published maps and institutional affiliations.

\section{Author details}

'Laboratory of Environmental Engineering and EcoTechnology, National Engineering School of Sfax (LR16ES19) (ENIS), Sfax University, Sfax, Tunisia. 2Lorraine University, Medical School, INGRES (EA 7298), Vandouure-les-Nancy, Nancy, France. ${ }^{3}$ EHESP School of Public Health, Rennes, France. ${ }^{4}$ Sfax University, Faculty of Medicine, Sfax, Tunisia. ${ }^{5}$ INSERM U1085 (IRSET), Rennes, France.

Received: 8 January 2017 Accepted: 20 February 2018

Published online: 05 March 2018

\section{References}

1. Khlifi R, Olmedo P, Gil F, Feki-Tounsi M, Hammami B, Rebai A, et al. Biomonitoring of cadmium, chromium, nickel and arsenic in general population living near mining and active industrial areas in southern Tunisia. Environ Monit Assess. 2014;186:761-79.

2. Detailed data table for the 2011 priority list of hazardous substances that will be the subject of toxicological profiles. Agency for Toxic Substances and Disease Registry (ATSDR); 2011. http://www.atsdr.cdc.gov/spl/resources/ ATSDR_2011_SPL_Detailed_Data_Table.pdf. Accessed 7 Feb 2014.
3. ATSDR. Toxicological Profile: Nickel. 2005. http://www.atsdr.cdc.gov/ ToxProfiles/tp.asp?id=245\&tid=44. Accessed 3 Jun 2016.

4. ATSDR. Toxicological Profile: Copper. 2004. http://www.atsdr.cdc.gov/ toxprofiles/tp.asp?id=206\&tid=37. Accessed 31 May 2016.

5. Garnier R. Toxicité du plomb et de ses dérivés. Pathol Prof Environ EMC. 2006:1:1-15.

6. ATSDR - Interaction Profile: Arsenic, Cadmium, Chromium and Lead.2004. http://www.atsdr.cdc.gov/interactionprofiles/ip04.html. Accessed 11 Feb 2014.

7. ATSDR. Toxicological Profile: Lead. 2007. http://www.atsdr.cdc.gov/ toxprofiles/tp.asp?id=96\&tid=22. Accessed 12 June 2016.

8. Barhoumi S, Messaoudi I, Deli T, Saïd K, Kerkeni A. Cadmium bioaccumulation in three benthic fish species, Salaria Basilisca, Zosterisessor Ophiocephalus and Solea Vulgaris collected from the Gulf of Gabes in Tunisia. J Environ Sci. 2009:21:980-4.

9. Kessabi K, Kerkeni A, Saïd K, Messaoudi I. Involvement of cd bioaccumulation in spinal deformities occurrence in natural populations of Mediterranean killifish. Biol Trace Elem Res. 2008;128:72-81.

10. Banni M, Jebali J, Daubeze M, Clerandau C, Guerbej H, Narbonne JF, et al. Monitoring pollution in Tunisian coasts: application of a classification scale based on biochemical markers. Biomarkers. 2005:10:105-16.

11. Jayjock MA, Chaisson CF, Arnold S, Dederick EJ. Modeling framework for human exposure assessment. J Expo Sci Environ Epidemiol. 2007;17:581-9.

12. AlHA Exposure Assessment Committee. Mathematical Models for Estimating Occupational Exposure to Chemicals. 2nd edition. USA: AlHA press; 2009.

13. Boelter FW, Simmons CE, Berman L, Scheff P. Two-zone model application to breathing zone and area welding fume concentration data. J Occup Environ Hyg. 2009;6:298-306

14. Kong IC. Joint effects of heavy metal binary mixtures on seed germination, root and shoot growth, bacterial bioluminescence, and gene mutation. J Environ Sci. 2013;25:889-94.

15. Martínez-Pacheco M, Hidalgo-Miranda A, Romero-Córdoba S, Valverde M, Rojas E. mRNA and miRNA expression patterns associated to pathways linked to metal mixture health effects. Gene. 2014;533:508-14.

16. Khlifi R, Olmedo P, Gil F, Feki-Tounsi M, Hammami B, Rebai A, et al. Risk of laryngeal and nasopharyngeal cancer associated with arsenic and cadmium in the Tunisian population. Environ Sci Pollut Res. 2013;21:2032-42.

17. Løkke H, Ragas AMJ, Holmstrup M. Tools and perspectives for assessing chemical mixtures and multiple stressors. Toxicology. 2013;313:73-82.

18. Gargouri D, Azri C, Serbaji MM, Jedoui Y, Montacer M. Heavy metal concentrations in the surface marine sediments of Sfax coast, Tunisia. Environ Monit Assess. 2010;175:519-30.

19. Hentati O, Chaker S, Wali A, Ayoub T, Ksibi M. Effects of long-term irrigation with treated wastewater on soil quality, soil-borne pathogens, and living organisms: case study of the vicinity of El Hajeb (Tunisia). Environ Monit Assess. 2013. https://doi.org/10.1007/s10661-013-3570-z. Accessed 7 Feb 2014

20. Ben Fredj F, Wali A, Khadhraoui M, Han J, Funamizu N, Ksibi M, et al. Risk assessment of heavy metal toxicity of soil irrigated with treated wastewater using heat shock proteins stress responses: case of El Hajeb, Sfax, Tunisia. Environ Sci Pollut Res. 2013. https://doi.org/10.1007/s11356-013-2411-5. Accessed 7 Feb 2014.

21. Serbaji MM, Azri C, Medhioub K. Anthropogenic contributions to heavy metal distributions in the surface and sub-surface sediments of the northern coast of Sfax. Tunisia Int J Environ Res. 2012;6:613-26.

22. Banni M, Bouraoui Z, Ghedira J, Clearandeau C, Jebali J, Boussetta H. Seasonal variation of oxidative stress biomarkers in clams Ruditapes decussatus sampled from Tunisian coastal areas. Environ Monit Assess. 2008; 155:119-28.

23. El Ati-Hellal M, Hedhili A, Hellal F, Boujlel K, Dachraoui M, Bousnina M, et al. Lead and cadmium concentrations in seawater and algae of the Tunisian coast. Arch Inst Pasteur Tunis. 2005:82:75-82.

24. Annabi A, Said K, Messaoudi I. Heavy metal levels in gonad and liver tissues-effects on the reproductive parameters of natural populations of Aphanius facsiatus. Environ Sci Pollut Res. 2013;20:7309-19.

25. Kessabi K, Annabi A, Hassine AlH, Bazin I, Mnif W, Said K, et al. Possible chemical causes of skeletal deformities in natural populations of Aphanius Fasciatus collected from the Tunisian coast. Chemosphere. 2013;90:2683-9.

26. Hamza-Chaffai A, Cosson RP, Amiard-Triquet C, El Abed A. Physico-chemical forms of storage of metals ( $\mathrm{cd}, \mathrm{cu}$ and $\mathrm{Zn}$ ) and metallothionein-like proteins in gills and liver of marine fish from the Tunisian coast: ecotoxicological 
consequences. Comp Biochem Physiol C Pharmacol Toxicol Endocrinol. 1995;111:329-41.

27. Kessabi K, Navarro A, Casado M, Saïd K, Messaoudi I, Piña B. Evaluation of environmental impact on natural populations of the Mediterranean killifish Aphanius Fasciatus by quantitative RNA biomarkers. Mar Environ Res. 2010; 70:327-33.

28. Hamza-Chaffai A, Roméo M, el Abed A. Heavy metals in different fishes from the middle eastern coast of Tunisia. Bull Environ Contam Toxicol. 1996;56:766-73.

29. Smaoui-Damak W, Berthet B, Hamza-Chaffai A. In situ potential use of metallothionein as a biomarker of cadmium contamination in Ruditapes decussatus. Ecotoxicol Environ Saf. 2009;72:1489-98.

30. Ketata I, Smaoui-Damak W, Guermazi F, Rebai T, Hamza-Chaffai A. In situ endocrine disrupting effects of cadmium on the reproduction of Ruditapes decussatus. Comp. Biochem. Physiol. Part C Toxicol. Pharmacol. 2007;146: 415-30.

31. Smaoui-Damak W, Berthet B, Rebai T, Hamza-Chaffai A. Effets de la pollution par les metaux sur le potentiel reproducteur de la palourde Ruditapes decussatus (L.) issue du Golfe de Gabes (Tunisie). Bull. Société Zool. Fr. 2008;133:131-9.

32. Lahbib Y, Mleiki A, Marigomez I, Trigui El Menif N. Copper, zinc, and cadmium body concentrations in Hexaplex trunculus collected from the Tunisian coast. Environ Monit Assess. 2013;185:8967-75.

33. Khlifi R, Olmedo P, Gil F, Hammami B, Chakroun A, Rebai A, et al. Arsenic, cadmium, chromium and nickel in cancerous and healthy tissues from patients with head and neck cancer. Sci Total Environ. 2013;452-453:58-67.

34. Khlifi R, Olmedo P, Gil F, Feki-Tounsi M, Chakroun A, Rebai A, et al. Blood nickel and chromium levels in association with smoking and occupational exposure among head and neck cancer patients in Tunisia. Environ Sci Pollut Res. 2013;20:8282-94.

35. Feki-Tounsi M, Olmedo P, Gil F, Khlifi R, Mhiri M-N, Rebai A, et al. Cadmium in blood of Tunisian men and risk of bladder cancer: interactions with arsenic exposure and smoking. Environ Sci Pollut Res. 2013;20:7204-13.

36. Khlifi R, Hamza-Chaffai A. Head and neck cancer due to heavy metal exposure via tobacco smoking and professional exposure: a review. Toxicol Appl Pharmacol. 2010;248:71-88.

37. Smaoui-Damak W, Rebai T, Berthet B, Hamza-Chaffai A. Does cadmium pollution affect reproduction in the clam Ruditapes decussatus? A one-year case study. Comp Biochem Physiol Part C Toxicol Pharmacol. 2006;143:252-61.

38. Saïdi SA, Azaza MS, Windmolders P, van Pelt J, El-Feki A. Cytotoxicity evaluation and antioxidant enzyme expression related to heavy metals found in tuna by-products meal: an in vitro study in human and rat liver cell lines. Exp Toxicol Pathol. 2013;65:1025-33.

39. Mezghani-Chaari S, Hamza A, Hamza-Chaffai A. Mercury contamination in human hair and some marine species from Sfax coasts of Tunisia: levels and risk assessment. Environ Monit Assess. 2011;180:477-87.

40. Gargouri I, Rebaï A, Khadhraoui M, Kallel M, Jmal-Hammami K, Medhioub K, et al. Impact sanitaire des variations quotidiennes de la pollution atmosphérique urbaine: étude de faisabilité dans la ville de Sfax (Tunisie). Environ. Risques Santé. 2006;5:467-75.

41. Chambre de commerce et d'industrie de Sfax, Tunisie. Guide des exportateurs de Sfax. Tunisie; 2010.

42. Committee on the Institutional Means for Assessment of Risks to Public Health, National Research Council, Division on Earth and Life Studies, Commission on Life Sciences. Risk Assessment in the Federal Government: Managing the Process. Washington, D.C.: National Academies Press; 1983.

43. InVS, Afsset. Estimation de l'impact sanitaire d'une pollution environnementale et évaluation quantitative des risques sanitaires. 2007. http://www.invs.sante.fr/publications/2008/pollution_invs_afsset/rap_ pollution_invs_afsset_nov_2007.pdf. Accessed 13 Dec 2014

44. Fairbrother A, Wenstel R, Sappington K, Wood W. Framework for Metals Risk Assessment. Ecotoxicol Environ Saf. 2007;68:145-227.

45. Bertrand N, Vincent R. Modélisation des expositions professionnelles aux agents chimiques. ND: Bilan et perspectives. Hygiène Sécurité Trav; 2010. http://www.inrs.fr/media.html?reflNRS=ND\%202333. Accessed 9 Feb 2014

46. INRS. Principe général et mise en oeuvre pratique du prélèvement. 2015. http://www.inrs.fr/dms/inrs/PDF/metropol-prelevement-principe.pdf. Accessed 16 Sept 2016.

47. METALS in Urine. http://www.cdc.gov/niosh/docs/2003-154/pdfs/8310.pdf. Accessed 18 Aug 2014

48. American Industrial Hygiene Association. Exposure Assessment Strategies Committee. https://www.aiha.org/get-involved/VolunteerGroups/Pages/ Exposure-Assessment-Strategies-Committee.aspx. Accessed 14 Nov 2016.
49. IHMod - Outil - INRS. http://www.inrs.fr/media.html?reflNRS=outil27. Accessed 14 Nov 2016.

50. Office of Air Quality Planning and Standards UE. Emissions Factors \& AP 42. https://www.epa.gov/air-emissions-factors-and-quantification/ap-42compilation-air-emission-factors. Accessed 19 May 2016.

51. Filter Cassettes, Blank, 37 mm, Clear Styrene, SKC, Inc. http://www.skcinc com/catalog/product_info.php?products_id=343. Accessed 13 Jun 2016.

52. INRS. Métaux et métalloïdes M-122 - MétroPol. 2016. http://www.inrs.fr/ publications/bdd/metropol/fiche.html?reflNRS=METROPOL_122. Accessed 13 Jun 2016.

53. Quartz Filters, $1.2 \mu \mathrm{m}, 37 \mathrm{~mm}$, Type R-100, SKC, Inc https://www.skcinc.com/ catalog/product_info.php?products_id=254. Accessed 13 Jun 2016.

54. Hassani H, Golbabaei F, Ghahri A, Hosseini M, Shirkhanloo H, Dinari B, et al. Occupational exposure to manganese-containing welding fumes and pulmonary function indices among natural gas transmission pipeline welders. J Occup Health. 2012;54:316-22.

55. Golbabaei F, Seyedsomea M, Ghahri A, Shirkhanloo H, Khadem M, Hassani $\mathrm{H}$, et al. Assessment of welders exposure to carcinogen metals from manual metal arc welding in gas transmission pipelines, Iran. Iran J Public Health. 2012;41:61-70.

56. Harper M, Pacolay B. A comparison of X-ray fluorescence and wet chemical analysis for lead on air filters from different personal samplers used in a secondary lead smelter/solder manufacturer. J Environ Monit. 2006;8:140.

57. OSHA Technical Center. Metal \& metalloid particulates in workplace atmosph eres (atomic absorption). 2002. https://www.osha.gov/dts/sttc/ methods/inorganic/id121/id121.pdf. Accessed 18 Aug 2014.

58. OSHA Technical Center. Metal and metalloid particulates in workplace atmos pheres (ICP analysis). 2002. https://www.osha.gov/dts/sltc/methods/ inorganic/id125g/id125g.pdf. Accessed 18 Aug 2014.

59. Nicas M, Plisko MJ, Spencer JW. Estimating benzene exposure at a solvent parts washer. J Occup Environ Hyg. 2006;3(5):284-91.

60. Plisko MJ, Spencer JW. Evaluation of a mathematical model for estimating solvent exposures in the workplace. J Chem Health Saf. 2008;15(3):14-21.

61. Nicas M, Neuhaus J. Predicting benzene vapor concentrations with a near field/far field model. J Occup Environ Hyg. 2008:5(9):599-608.

62. Spencer JW, Plisko MJ. A comparison study using a mathematical model and actual exposure monitoring for estimating solvent exposures during the disassembly of metal parts. J Occup Environ Hyg. 2007;4(4):253-9.

63. Mumtaz M, Fisher J, Blount B, Ruiz P. Application of physiologically based Pharmacokinetic models in chemical risk assessment. J Toxicol. 2012;2012:1-11.

64. von Stackelberg K, Guzy E, Chu T, Henn BC. Mixtures, Metals, Genes and Pathways: A Systematic Review. 2013. https://cdn1.sph.harvard.edu/wpcontent/uploads/sites/1273/2013/09/von-Stackelberg-et-al.-Sept-2013.pdf. Accessed 10 Feb 2014

65. Sasso AF, Isukapalli SS, Georgopoulos PG. A generalized physiologicallybased toxicokinetic modeling system for chemical mixtures containing metals. Theor Biol Med Model. 2010;7:17.

66. Teuschler L. Deciding which chemical mixtures risk assessment methods work best for what mixtures. Toxicol Appl Pharmacol. 2007;223:139-47.

67. Hertzberg RC, Teuschler LK. Evaluating quantitative formulas for doseresponse assessment of chemical mixtures. Environ Health Perspect. 2002; 110:965-70.

68. EPA. Supplementary Guidance for Conducting Health Risk Assessment of Chemical Mixtures. http://ofmpub.epa.gov/eims/eimscomm.getfile?p_ download_id=4486. Accessed 24 Dec 2015.

69. IRSST. Mixie: Mixtures of substances in the workplace: computer-based tool for evaluating the chemical risk. 2014. http://www.irsst.qc.ca/en/publications-tools/ tool/i/100037/n/mixie-mixtures-substances-workplace-evaluating-chemical-risk. Accessed 31 Mar 2014

70. MiXie - Interactions toxicologiques. http://www.inrs-mixie.fr/. Accessed 25 Aug 2014.

71. Office of Air Quality Planning and Standards, US EPA. Chapter 12: Metallurgical Industry,s19: Electric Arc Welding. Emiss. Factors AP 42 Compil. Air Pollut. Emiss. Factors. Fifth Edition. https://www3.epa.gov/ttn/chief/ap42/ ch12/index.html. Accessed 10 May 2016.

72. OK 48.00 With ESAB. http://www.esab.fr/france-benelux/fr/products/index. $\mathrm{cfm} ?$ fuseaction=home.product\&productCode $=410005 \&$ tab $=2$. Accessed 18 May 2016.

73. AWS E6013 Welding Electrode. http://www.tenweld.com/aws-e6013welding-electrode.html. Accessed 12 Oct 2016. 
74. Schneider T, Kildes J, Breum NO. A two compartment model for determining the contribution of sources, surface deposition and resuspension to air and surface dust concentration levels in occupied rooms. Build Environ. 1999:34(5):583-95.

75. Health Canada. ARCHIVED - health-based tolerable daily intakes/ concentrations and tumorigenic doses/concentrations for priority substances. 2013. http://publications.gc.ca/site/eng/411636/publication.html. Accessed 25 May 2016.

76. Canadian Environmental Protection Act. Priority substances list supporting documentation: health-based tolerable daily intakes/concentrations and Tumourigenic doses/concentrations for priority substances: Health Canada 1996. http://www.tera.org/iter/HCPSL1supportdoc.pdf. Accessed 2 June 2016

Submit your next manuscript to BioMed Central and we will help you at every step:

- We accept pre-submission inquiries

- Our selector tool helps you to find the most relevant journal

- We provide round the clock customer support

- Convenient online submission

- Thorough peer review

- Inclusion in PubMed and all major indexing services

- Maximum visibility for your research

Submit your manuscript at www.biomedcentral.com/submit
Biomed Central 